\title{
Chayote mosaic virus, a New Tymovirus Infecting Cucurbitaceae
}

\author{
Juan J. Bernal, Ignacio Jiménez, Manuel Moreno, Melanie Hord, \\ Carmen Rivera, Renate Koenig, and Emilio Rodríguez-Cerezo
}

First, second, third, and seventh authors: Centro Nacional de Biotecnología (CNB-CSIC), Cantoblanco, 28049 Madrid, Spain; fourth and fifth authors: Centro de Investigación en Biología Celular y Molecular, Universidad de Costa Rica, San José; and sixth author: Biologische Bundesanstalt für Land- und Forstwirtschaft, Institut für Pflanzenvirologie, Mikrobiologie und biologische Sicherheit, Germany. Accepted for publication 10 July 2000.

\begin{abstract}
Bernal, J. J., Jiménez, I., Moreno, M., Hord, M., Rivera, C., Koenig, R., and Rodríguez-Cerezo, E. 2000. Chayote mosaic virus, a new tymovirus infecting Cucurbitaceae. Phytopathology 90:1098-1104.

Chayote mosaic virus (ChMV) is a putative tymovirus isolated from chayote crops in Costa Rica. ChMV was characterized at the host range, serological, and molecular levels. ChMV was transmitted mechanically and induced disease symptoms mainly in Cucurbitaceae hosts. Asymptomatic infections were detected in other host families. Serologically, ChMV is related to the Andean potato latent virus (APLV) and the Eggplant mosaic virus (EMV), both members of the genus Tymovirus infecting solanaceous hosts in the Caribbean Basin and South America.

The sequence of the genomic RNA of ChMV was determined and its genetic organization was typical of tymoviruses. Comparisons with other tymoviral sequences showed that ChMV was a new member of the genus Tymovirus. The phylogenetic analyses of the coat protein gene were consistent with serological comparisons and positioned ChMV within a cluster of tymoviruses infecting mainly cucurbit or solanaceous hosts, including APLV and EMV. Phylogenetic analyses of the replicase protein gene confirmed the close relationship of ChMV and EMV. Our results suggest that ChMV is related to two tymoviruses (APLV and EMV) of proximal geographical provenance but with different natural host ranges. ChMV is the first cucurbit-infecting tymovirus to be fully characterized at the genomic level.
\end{abstract}

The genus Tymovirus comprises at least 20 species of plant viruses transmitted by beetles and occasionally by seed. These viruses have isometric particles (28-nm diameter) and a singlestranded RNA genome approximately $6.4 \mathrm{~kb}$ in length. Sequence analysis has revealed that the tymovirus genome codes for three proteins $(8,9,24,32,34,41)$. The replicase protein $(\mathrm{RP})$ and the movement protein (also named overlapping protein, OP) are encoded by overlapping reading frames at the $5^{\prime}$ and central portions of the RNA, while the capsid protein (CP) gene is located in the $3^{\prime}$ portion. Replication likely occurs in association with formation of membrane vesicles in the chloroplast periphery. These vesicles are cytopathic effects typical of the tymoviruses and have diagnostic value (28).

Tymoviruses have been isolated from several families of dicotyledonous plants, mainly from weeds but also from some cultivated plants (20). Each Tymovirus sp. has a host range that is usually quite narrow, restricted to a few host plants belonging to the same family or to a small number of related families (15). Also, most tymoviruses have a restricted geographical distribution that may be related to the characteristics of their insect vectors.

A virus causing a disease in chayote (Sechium edule (Jacq) Sw.; Cucurbitaceae), a cultivated cucurbit native to Central America, was recently described (21). The virus was named Chayote mosaic virus (ChMV) and tentatively grouped with the tymoviruses, because of its particle morphology, cytopathological effects on infected chayote cells, and the sizes of its coat protein and genomic RNA (21). ChMV has been isolated to date only in Costa Rica. So far, two other tymoviruses have been isolated from $\mathrm{Cu}-$ curbitaceae: Wild cucumber mosaic virus (WCMV) and Melon

Corresponding author: E. Rodríguez-Cerezo; E-mail address: erguez@ cnb.uam.es

Publication no. P-2000-0801-01R

(C) 2000 The American Phytopathological Society rugose mosaic virus (MRMV) (22,31). WCMV infects weeds in the United States (31), whereas MRMV has been found only in Yemen and Sudan infecting cucurbit crops $(22,30)$. These two viruses do not cross-react serologically (22).

In this paper we describe the experimental host range of ChMV. We also analyze the serological cross-reactivities of ChMV and report the complete nucleotide sequence (nt) of its genomic RNA. Our data demonstrate that ChMV is a new species of the genus Tymovirus. In addition, serological, sequence, and phylogenetic comparisons of ChMV show the closest relationship with the two Solanaceae-infecting tymoviruses reported from South America and the Caribbean, Andean potato latent virus (APLV) and Eggplant mosaic virus (EMV).

\section{MATERIALS AND METHODS}

Viruses. The tymoviruses used in serological comparisons are included in Table 1 and belonged to the stock of the Institut für Pflanzenvirologie, Mikrobiologie, and biologische Sicherheit in Braunschweig, Germany. The ChMV isolate characterized here was obtained in Costa Rica from commercial chayote fields and was maintained in chayote plants.

Experimental host range and natural hosts. Seedlings of 25 plant species (Table 2) were inoculated by rubbing cotyledons or leaves dusted with Carborundum with sap from infected chayote plants $(1: 5, \mathrm{wt} / \mathrm{vol})$ or with purified virus particles in $0.1 \mathrm{M}$ $\mathrm{Na}_{2} \mathrm{HPO}_{4}-\mathrm{KH}_{2} \mathrm{PO}_{4}, \mathrm{pH}$ 7.0. Test plants were observed daily for symptom development during the 3 -week period following the inoculation. Newly developed leaves were collected after a minimum of 2 weeks and infection was confirmed by double-antibody sandwich-enzyme-linked immunosorbent assay (DAS-ELISA) using polyclonal antibodies specific for ChMV (21). Leaf tissue of field-grown Frantzia tacaco, Cyclanthera pedata, and Cucurbita pepo with symptoms of mosaic and leaf deformation were collected near areas of commercial chayote production. Samples were analyzed for the presence of ChMV by DAS-ELISA. 
Purification of ChMV virions and RNA. ChMV-infected chayote-leaf tissue was used for virus and encapsidated RNA purification as previously described (21). RNA integrity was tested and confirmed by electrophoresis under denaturing conditions in agarose gels using standard protocols.

Serological analyses. Double diffusion tests (1) were done in $0.85 \%$ agar, $0.01 \mathrm{M}$ Tris $\mathrm{HCl}$ buffer ( $\mathrm{pH} 8.0$ ), containing $0.85 \%$ sodium chloride. The wells were 4-mm in diameter, spaced $2.5 \mathrm{~mm}$ apart. All polyclonal antisera were from the stock of the Institut für Pflanzenvirologie, Mikrobiologie, and Biologische Sicherheit (Braunschweig, Germany) (26,27), except antiserum to ChMV, which was prepared by Hord et al. (21).

Cloning strategy and sequence determination. A cDNA library was constructed by random priming and reverse transcription of genomic RNA (gRNA) of ChMV. For cDNA synthesis we used Moloney murine leukemia virus reverse transcriptase (Promega Corp., Madison, WI) following the manufacturer's protocol. Double-stranded cDNA was obtained with DNA polymerase I and RNase H (Promega) as described (39) and was cloned into pUC19 digested with SmaI (Promega). A number of clones from this library were sequenced using a 373 DNA Sequencing System (Perkin-Elmer Applied Biosystems, Foster City, CA) and lined up with the tymovirus genetic map (Fig. 1). Sequence information of one of the clones was used for specific cloning of the $5^{\prime}$ end by rapid amplification of cDNA ends (RACE). ChMV gRNA was reverse transcribed with an oligonucleotide primer complementary to positions 371 through 349 of the gRNA (5'-GGTCTCGAGGACCTTGTGAACTG-3'). The single-stranded cDNA was purified with the High Pure PCR Product Purification Kit (Boehringer GmbH, Mannheim, Germany) and a poly(A) tail was added to the $3^{\prime}$ end, using terminal transferase $(\mathrm{GmbH})$. A specific dsDNA of $\approx 400 \mathrm{nt}$ was amplified by polymerase chain reaction (PCR) with the oligonucleotide described above and a $(\mathrm{dT})_{16}$ oligomer. The PCR product was cloned as described above and several clones were sequenced. In addition, sequence of the $5^{\prime}$-terminal part of the genome was also determined by direct sequencing of purified gRNA (12) with an oligonucleotide primer complementary to positions 64 through 79 (5'-CTTTCACGTGGGAAGG-3'). The $3^{\prime}$-terminal residues of ChMV gRNA were determined by labeling the $3^{\prime}$ end with $\left[5^{\prime}-{ }^{32} \mathrm{P}\right] \mathrm{pCp}$ and T4 RNA ligase (New England Biolabs Inc.,
Beverly, MA) followed by controlled enzymatic degradation of the labeled fragments with specific ribonucleases T1 (Sigma Chemical Co., St. Louis), U2, and Phy M (Amersham Pharmacia Biotech, Uppsala, Sweden) as described (2). Further confirmation of the $3^{\prime}$-end sequence was carried out by cloning the last $570 \mathrm{nt}$. cDNA clones from this region were obtained by reverse transcription (RT)-PCR after adding a poly(A) tail to the gRNA with yeast poly(A) polymerase (Amersham Pharmacia Biotech) with a $(\mathrm{dT})_{16}$ oligomer and the oligonucleotide 5'-CTGTCGAAACCGCCTTC-3' (positions 5795 through 5811 of ChMV gRNA).

The presence of a cap structure in the $5^{\prime}$ end of ChMV gRNA was investigated using a three-step procedure. ChMV gRNA was incubated with a decapping enzyme (tobacco acid pyrophosphatase; Epicentre Technologies, Madison, WI) followed by a dephosphorylation reaction with calf intestinal alkaline phosphatase $(\mathrm{GmbH})$ according to procedures recommended by the suppliers. ChMV gRNA was radiolabeled at the $5^{\prime}$ end with $\left[\gamma{ }^{32} \mathrm{P}\right] \mathrm{ATP}$ in the presence of $T 4$ polynucleotide kinase (New England Biolabs) (39), and analyzed by autoradiograms after agarose gel electrophoresis.

Once the sequences of both ends of ChMV gRNA were determined, and with the aid of the internal sequences obtained from the random-primed cDNA library, we designed several oligonucleotide primers to synthesize three overlapping cDNA clones that encompass the entire gRNA (clones $\mathrm{ChA}, \mathrm{ChB}$, and $\mathrm{ChC}$ ) (Fig. 1). These cDNAs were made by RT-PCR of gRNA with a mixture of Taq (Sigma) and $P f u$ (Stratagene Inc., La Jolla, CA) DNA polymerases followed by cloning into pUC19. Clones were sequenced automatically with DNA sequencing system.

Sequence and phylogenetic comparisons and secondary structure analyses. Nucleotide sequences as well as the putative amino acid sequences were analyzed using the GCG program package (Genetics Computer Group, Madison, WI). Sequence data were used to obtain phylogenies by the Wagner parsimony or the neighbor-joining methods $(25,38)$. Multiple alignments of the nucleotide sequences were done with the program CLUSTALW (42) and the genetic distances were estimated by Blosum 30 (19). For parsimony comparisons we used the PHYLIP 3.572 package (J. Felsenstein, Seattle, WA). RNA secondary structure predictions were done with MFOLD (44) and STAR $4.0(43,44)$.

TABLE 1. Names and acronyms of viruses used in serological and phylogenetic comparisons with Chayote mosaic virus

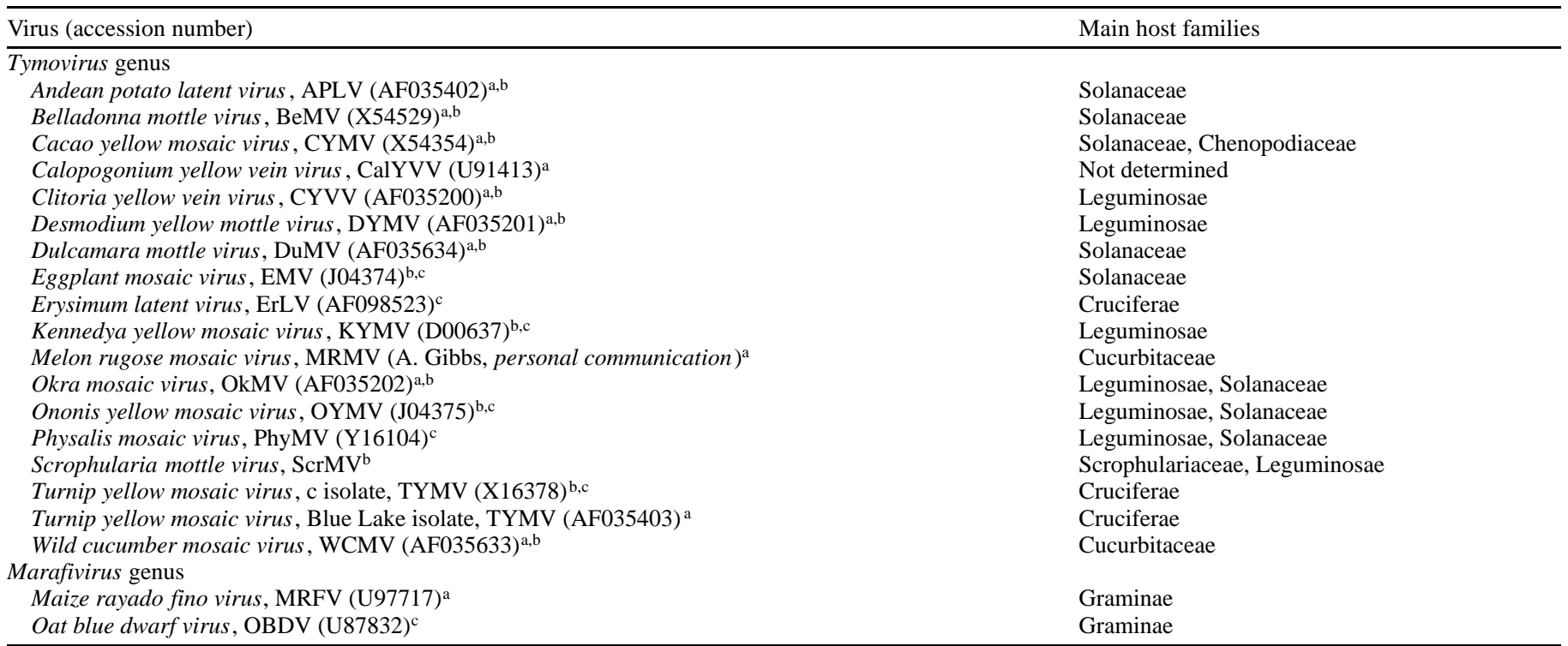

${ }^{a}$ Only coat protein sequence data is available.

b Virus used for serological analyses.

c The complete genomic sequence is known. 


\section{RESULTS}

Experimental host range and natural hosts. The experimental host range studies are summarized in Table 2. These data showed that ChMV induced disease symptoms only in some cucurbits and one solanaceous species. Symptoms of systemic infection including mosaic and corrugation were observed in the cucurbits Citrullus vulgaris, Cucumis melo, Cyclanthera pedata, Luffa cylindrica, Sechium edule, and in the Solanaceous Nicotianae benthamiana. In all cases, infection by ChMV was confirmed by DAS-ELISA. Asymptomatic systemic infection was occasionally detected by DAS-ELISA in plants of Gomphrena globosa, Brassica rapa L. subsp. rapifera, Pisum sativum, Datura stramonium, Petunia $\times$ hybrida, and Solanum tuberosum. The experimental host range of ChMV did not correspond to the host range of any other known tymovirus. In natural conditions, ChMV was identified only in symptomatic samples of chayote and of Frantzia tacaco, another cucurbit native to Costa Rica and occasionally cultivated. Unfortunately, we were not able to germinate seeds of $F$. tacaco under experimental conditions, so this species was not included in the greenhouse analyses.

Serological comparison of ChMV with other tymoviruses. Sap from ChMV-infected leaves was used in agar gel double diffusion tests with antisera developed to a collection of established and tentative species within the genus Tymovirus (Table 1). In preliminary experiments, ChMV failed to react with antiserum to Wild cucumber mosaic virus (WCMV), another tymovirus infecting mainly species in the Cucurbitaceae (data not shown). Likewise, either a very weak or no reaction was observed with antisera to the following tymoviruses: Tobacco yellow mosaic virus (TYMV), Dicliptera yellow mottle virus (DYMV), Kennedya yellow mosaic virus (KYMV), Okra mosaic virus (OkMV), Clito- ria yellow vein virus (CYVV), Cacao yellow mosaic virus (CYMV), Ononis yellow mosaic virus (OYMV), Scrophularia mottle virus (ScrMV), Dulcamara mottle virus (DuMV), and Belladonna mottle virus (BeMV). However, ChMV reacted strongly with antisera to several strains of EMV and APLV, i.e., the type and Abelia latent strains of EMV and the $\mathrm{Hu}, \mathrm{Col1}, \mathrm{Col} 2$, and Caj strains of APLV (27) (data not shown). The precipitin lines formed by these antisera with their complementary antigens spurred over those formed with ChMV indicating that, although ChMV clearly belonged to the APLV/EMV cluster (26), it was not identical to any of the APLV and EMV strains tested. In reciprocal experiments, an antiserum prepared to ChMV also reacted strongly with strains of the APLV/EMV cluster (Fig. 2), very faintly with BeMV (Fig. 2), and again very faintly with DuMV, OYMV, ScrMV, and WCMV (data not shown). The precipitin lines produced with this antiserum and ChMV formed pronounced spurs over those formed with the other tymoviruses (Fig. 2). The relationship of ChMV with the APLV/EMV cluster was surprising, because these viruses mainly infect solanaceous hosts rather than species in Cucurbitaceae. As shown below, sequence and phylogenetic analyses of the $\mathrm{CP}$ gene of $\mathrm{ChMV}$ confirmed these results.

Genetic organization of ChMV RNA. The nucleotide sequence of ChMV genomic RNA (gRNA) was determined with the cloning strategy outlined in Figure 1 and shown to be 6,364 nt long. The nucleotide sequence has been submitted to the GenBank (Accession No. AF195000) and is not duplicated here. The gRNA of ChMV showed features typical of the tymoviruses. The base composition had a high proportion of cytosine residues $(18.4 \% \mathrm{~A}$, $24.8 \% \mathrm{U}, 40.8 \% \mathrm{C}$, and $16 \% \mathrm{G}$ ), a property of all tymovirus genomes. This feature could have strong implications for the secondary structure and the encapsidation of the gRNA (16). The

TABLE 2. Experimental host range of Chayote mosaic virus

\begin{tabular}{|c|c|c|c|}
\hline \multirow[b]{3}{*}{ Family } & \multirow[b]{3}{*}{ Species } & \multicolumn{2}{|c|}{ Infected plants $/$ Inoculated plants } \\
\hline & & \multicolumn{2}{|c|}{ Inoculum } \\
\hline & & Sap & Purified virus $^{\mathrm{b}}$ \\
\hline Amaranthaceae & Gomphrena globosa L. & $10 / 18$ & nt \\
\hline Chenopodiaceae & Chenopodium amaranticolor $\mathrm{L}$. & $0 / 12$ & $0 / 16$ \\
\hline Cruciferae & $\begin{array}{l}\text { Brassica campestris L. sp. pekinensis } \\
\text { Brassica rapa L. sp. rapifera }\end{array}$ & $\begin{array}{l}0 / 20 \\
5 / 12\end{array}$ & $\begin{array}{l}0 / 15 \\
1 / 16\end{array}$ \\
\hline Cucurbitaceae & $\begin{array}{l}\text { Citrullus vulgaris Schrader } \\
\text { Cucumis melo L. } \\
\text { Cucumis sativus L. } \\
\text { Cucurbita ficifolia Bouché } \\
\text { Cucurbita maxima L. } \\
\text { Cucurbita pepo L. } \\
\text { Cyclanthera pedata } \text { (L.) Schrader } \\
\text { Luffa cylindrica (L.) Roemer } \\
\text { Sechium edule (Jacq.) Sw. }\end{array}$ & $\begin{array}{r}9 / 12 \\
12 / 24 \\
0 / 20 \\
0 / 12 \\
0 / 12 \\
0 / 20 \\
8 / 24 \\
7 / 10 \\
31 / 50\end{array}$ & $\begin{array}{c}1 / 8 \\
15 / 18 \\
0 / 14 \\
0 / 8 \\
0 / 14 \\
0 / 14 \\
10 / 13 \\
4 / 13 \\
15 / 19\end{array}$ \\
\hline Leguminosae & $\begin{array}{l}\text { Phaseolus vulgaris L. } \\
\text { Pisum sativum L. } \\
\text { Vicia faba L. }\end{array}$ & $\begin{array}{l}0 / 33 \\
2 / 12 \\
0 / 12\end{array}$ & $\begin{array}{l}0 / 21 \\
\text { nt } \\
\text { nt }\end{array}$ \\
\hline Malvaceae & Hibiscus esculentus L. & $0 / 12$ & nt \\
\hline Solanaceae & $\begin{array}{l}\text { Datura stramonium } \mathrm{L} . \\
\text { Lycopersicon esculentum Mill. } \\
\text { Nicotiana benthamiana } \mathrm{L} . \\
\text { Nicotiana glutinosa } \mathrm{L} . \\
\text { Nicotiana tabacum } \mathrm{L} . \\
\text { Petunia } \times \text { hybrida } \\
\text { Solanum melongena } \mathrm{L} . \\
\text { Solanum tuberosum } \mathrm{L} .\end{array}$ & $\begin{array}{r}3 / 24 \\
0 / 20 \\
13 / 13 \\
0 / 12 \\
0 / 20 \\
5 / 12 \\
0 / 20 \\
2 / 12\end{array}$ & $\begin{array}{l}\mathrm{nt} \\
0 / 16 \\
3 / 13 \\
0 / 16 \\
\mathrm{nt} \\
8 / 28 \\
0 / 14 \\
\mathrm{nt}\end{array}$ \\
\hline
\end{tabular}

\footnotetext{
a Estimated by DAS-ELISA at 14 days after inoculation.
}

${ }^{\mathrm{b}} \mathrm{nt}=$ Not tested. 
existence of a methyl guanosine cap at the $5^{\prime}$ end of ChMV gRNA was investigated by $5^{\prime}$ end labeling of full-length gRNA with $\left[\gamma^{32} \mathrm{P}\right] \mathrm{ATP}$. No radioactive labeling was detected unless ChMV gRNA was previously treated with tobacco acid pyrophosphatase (data not shown), a result suggesting that the ChMV gRNA contains a cap structure at this position. The nucleotide sequence at the $5^{\prime}$ terminus of the gRNA was determined from five independent cDNA clones. The sequences were identical and began with two $\mathrm{G}$ residues. Thus, ChMV gRNA sequence starts 5'GpppGUAA-3', as do gRNAs of fully sequenced tymoviruses, except Physalis mosaic virus (PhyMV) (34). The genetic organization of ChMV gRNA was similar to those of other sequenced tymoviruses $(8,9,24,32,34,41)$. There were three major open reading frames (ORFs) corresponding to the replicase (RP), overlapping (OP), and coat protein (CP) genes (Fig. 1). As in other tymoviruses, in ChMV gRNA only four nt separate the two AUG codons of the overlapping RP and OP ORFs, and the RP gene is in the +1 frame with respect to the OP gene. The CP ORF of ChMV, in contrast to those of other tymoviruses, is separated from the RP ORF by a short (7 nt) intercistronic region (Fig. 1).

Noncoding regions. The first ORF in ChMV gRNA was preceded by a $5^{\prime}$ leader sequence of 139 residues, an intermediate length between those reported for tymovirus genomes, ranging between 171 (OYMV) and 78 nt (KYMV). Despite a high sequence and length variability, structure probing and computer predictions have recently shown remarkable similarities in the secondary structure of the $5^{\prime}$ noncoding leaders of five tymoviruses. Depending on the virus, there are either two or four hairpins with protonatable internal loops consisting of C-C or C-A mismatches (17). Our secondary structure prediction for the $5^{\prime}$-leader sequence of ChMV gRNA was peculiar since it showed the existence of three imperfect hairpins with internal loops containing C$\mathrm{C}$ mismatches of the type characteristic of other tymoviral 5'leader sequences (Fig. 3). As in other tymoviruses, the last hairpin of ChMV 5'-leader sequence occurred immediately before the first AUG start codon (Fig. 3). Results from studies with TYMV assigned functional roles, such as virus assembly, for these hairpins and the $\mathrm{C}-\mathrm{C}$ or $\mathrm{C}-\mathrm{A}$ mismatches are essential for an efficient accumulation of the virus in systemic leaves (18). Besides of its implication in virus assembly, the tymoviral leader sequence is involved in initiation of translation, and it cannot be excluded that its secondary structure could determine the choice of one of the two start codons for the 5'-proximal overlapping genes (18).
ChMV has a 3 '-noncoding region (130 nt) after the $\mathrm{CP}$ gene and the gRNA ends with the residues -CCA conserved in all tymoviruses analyzed. Part of the 3 '-noncoding region of the type member of the tymoviruses, TYMV, can be folded into a tRNA-like structure that is aminoacylatable $(10,33,35)$. The secondary structure analyses for the ChMV 3' end showed significant basepairing, and predicted the presence of a tRNA-like structure (data not shown) similar to those of TYMV and other tymoviruses (10). Although the tRNA-like structure may be important in TYMV biology, the initiation of minus-strand RNA synthesis in vitro by an RNA-dependent RNA polymerase seems to depend only on the non-base-paired -CCA end, or on the combination of nonspecific secondary structures and C-C-purine boxes at the $3^{\prime}$ end $(6,40)$.

A 16-nt conserved block of sequence named the tymobox was identified between residues 5624 and 5640 of ChMV gRNA. The tymobox is thought to be the CP mRNA promoter and is located $8 \mathrm{nt}$ upstream of the consensus box (5' CAAU $\left.3^{\prime}\right)$ for initiation of transcription of subgenomic RNA (7). The tymobox has been recently identified in a member of the related group of the marafiviruses (11). Alignment of the conserved tymobox sequences has been made with the purpose of designing genus-specific probes for detecting tymoviruses (7). Only the cucurbit-infecting WCMV was not detected with a consensus tymobox probe (7) since its sequence differed in four positions from the most common tymobox. Our analysis showed that the cucurbit-infecting ChMV had a tymobox sequence very different from WCMV (6 changes in 16 residues) and similar ( 2 changes in 16 residues) to the common tymobox sequence.

Characteristics of predicted gene products. Three long ORFs were found in the positive strand of ChMV gRNA, similar in size and arrangement to other tymovirus genomes. The largest ORF (residues 147 through 5654) was identified as the tymoviral replicase protein (Fig. 1). ChMV RP was predicted to be 1,835 amino acids long with an $M_{r}$ of $203.5 \mathrm{kDa}$. The RP of the type member of the tymoviruses, TYMV, is a polyprotein that contains a proteinase activity belonging to the papain-like superfamily of viral proteinases, and undergoes autoproteolysis to yield two functional polypeptides: the N-terminal methyltransferase/helicase proteinase and the C-terminal polymerase (36). The proteinase domain of TYMV RP has been mapped and two residues (Cys 783 and His 869) are essential for the proteinase active site (4). ChMV RP contained the two conserved active site residues in positions Cys 768 and His 854 and another amino acid (G 806) also present in

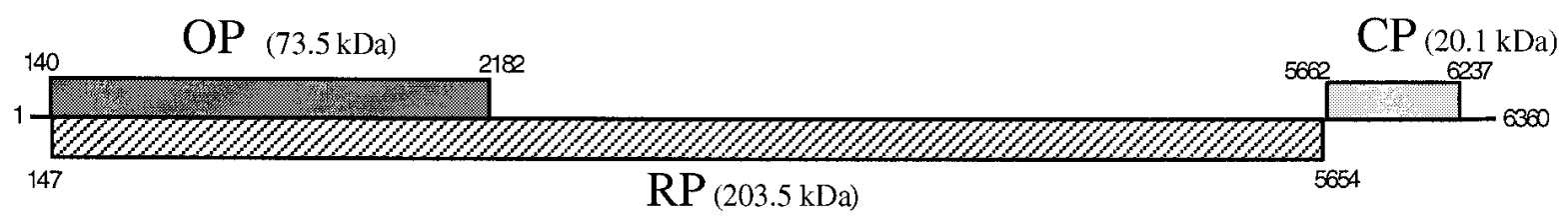

c 15

$\overline{\mathrm{c} 99}$ c 20

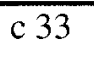

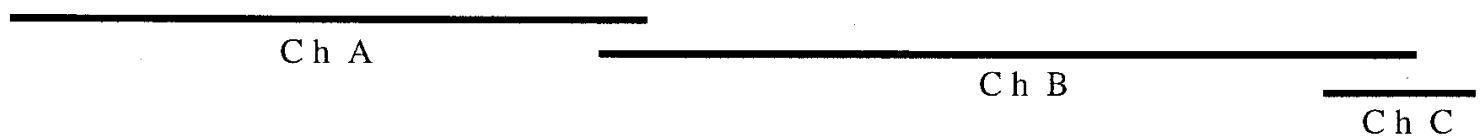

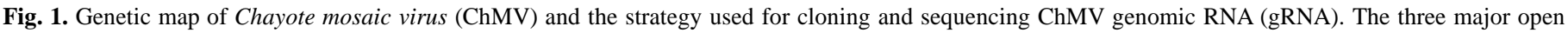

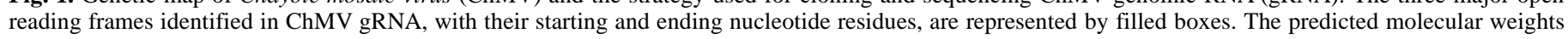

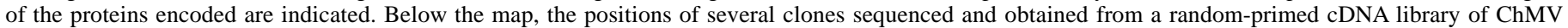

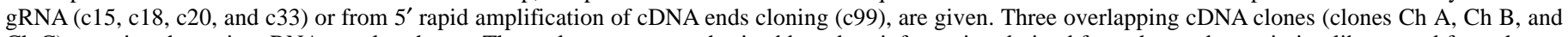

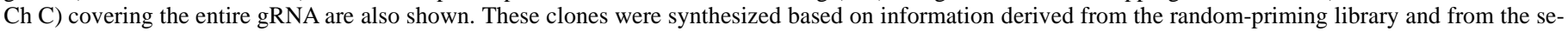
quences of the $5^{\prime}$ - and $3^{\prime}$-termini of ChMV gRNA as described in the text. 
all tymo-like proteinase domains (36). The cleavage site in TYMV RP lies between amino acid residues 1259 (Ala) and 1260 (Thr) (5) and is surrounded by residues poorly conserved among tymoviruses. Therefore, a putative cleavage site in ChMV RP could not be predicted with confidence (data not shown). In addition to the papain-like proteinase domains, other sequence motifs conserved in plant viral RPs could be identified in ChMV RP, including the four motifs of the N-methyltransferase domain (37), the six motifs of the RNA helicase superfamily $1(14,23)$ and the four conserved motifs of RNA-dependent RNA polymerases of positive-strand RNA viruses (including the GDD motif, in amino acids 1654 through 1656 of ChMV RP) (29).

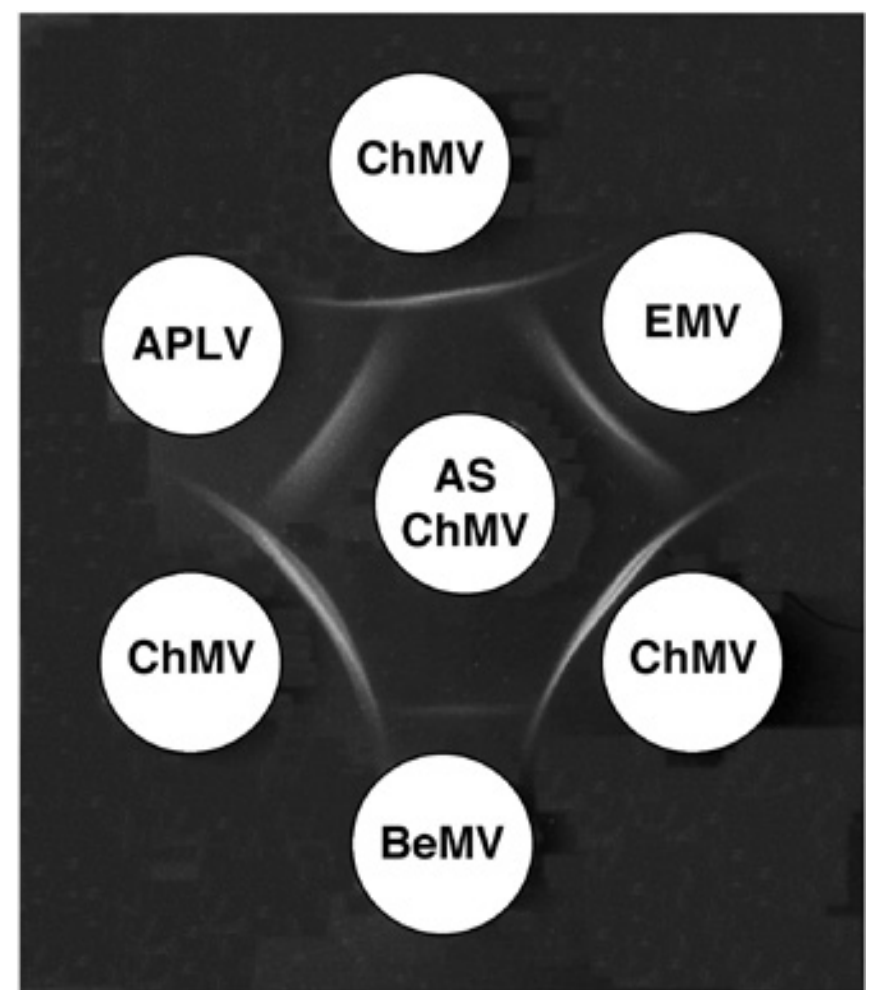

Fig. 2. Serological relationships of Chayote mosaic virus (ChMV) with other tymoviruses. Reaction of an antiserum to ChMV (central well) with the homologous virus, the type strain of Eggplant mosaic virus, Andean potato latent virus-Col1, and Belladonna mottle virus. Note that the precipitin lines formed with the homologous virus spur over those formed with the heterologous viruses.
The ChMV OP ORF (residues 140 through 2182 in ChMV gRNA) encoded a protein of 680 amino acids with an $\mathrm{Mr}$ of $73.5 \mathrm{kDa}$, the second largest among the six tymoviral OPs sequenced (ranging between 753 and 440 amino acids). Although tymoviral OPs are variable in length and sequence, they are all very basic proteins (pI 12.1 for ChMV OP) with an unusual high proline content (21.6\% for ChMV OP) that may confer on them a very distinct protein structure. OP is the movement protein of tymoviruses (3), but they are poorly characterized since genetic analyses are complicated due to the overlapping nature of OP and RP genes. The shorter and 3'-proximal ORF of ChMV corresponded to the CP gene (nt residues 5662 through 6237), which encoded a coat protein of 191 amino acids and a predicted Mr of $20.1 \mathrm{kDa}$. These data are consistent with the CP size of other tymoviruses and with the results of SDS-polyacrylamide gel electrophoretic analysis of a single protein found in purified ChMV preparations (21).

Sequence comparisons and phylogenetic analyses. The nucleotide sequence of ChMV CP gene was compared with that of 16 tymovirus species, including the two cucurbit-infecting tymoviruses described to date (Table 1). Neighbor-joining or parsimony trees were calculated using a marafivirus $\mathrm{CP}$ gene sequence (MRFV) as an outgroup. Both types of analyses gave similar results and classified the tymovirus species into two clusters, with bootstrap values above $95 \%$. One cluster contains the species infecting mainly Cruciferae and Leguminosae (Erysimum latent virus [ErLV], DYMV, Calopogonium yellow vein virus [CalYVV], KYMV, OkMV, CYMV, CYVV, TYMV, and TYMVbl), and the second cluster groups the Solanaceae- and cucurbitinfecting tymoviruses (BeMV, DuMV, OYMV, Melon rugose mosaic virus [MRMV], PhyMV, APLV, EMV, WCMV, and ChMV). A similar tree has been recently described (13). The ChMV CP gene is grouped in the second cluster, although relationships among members of this cluster could not accurately be established due to the low significance of bootstrap values. However, the highest amino acid sequence identity of ChMV with tymoviral CPs was found with APLV and EMV (54.4 and 51.6\%, respectively), and lowered to 45 to $46 \%$ with the two cucurbitinfecting viruses, MRMV and WCMV, suggesting that ChMV is more closely related to the APLV/EMV pair. These results correlate with the serological analyses presented here, in which ChMV was shown to be closely related to several APLV/EMV strains and distantly related to other members of the proposed cluster.

The sequences of the OP and RP genes of ChMV were also used in comparisons with the six tymoviruses for which complete genomic sequences were available (Table 1). Consensus trees

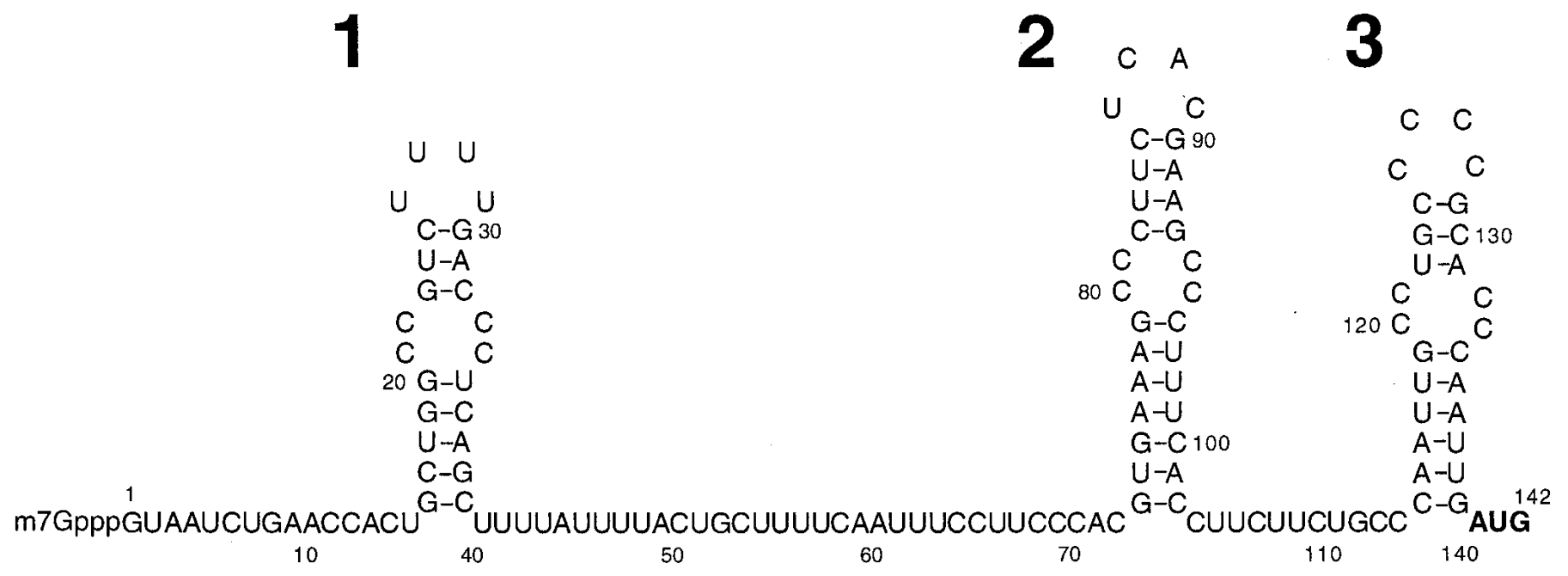

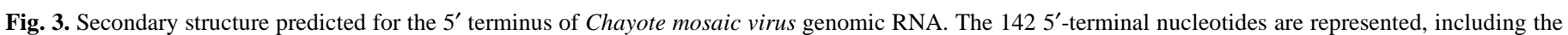
first AUG codon (bold). Three hairpins with internal loops are predicted (1 to 3 ). 
calculated with OPs were of low significance probably due to very low conservation among tymoviruses (the sequence identities among tymoviral OP proteins were lower than 38\%). The RP protein is fairly conserved among tymoviruses and for ChMV the highest identities were found with EMV and PhyMV (57.9 and $58.9 \%$, respectively), both infecting Solanaceae hosts. Consensus neighbor joining or parsimony trees calculated from RP differences were similar to each other and to that previously reported (34), and placed ChMV closest to EMV and PhyMV (data not shown).

\section{DISCUSSION}

The biological, serological, and genomic analyses presented here demonstrate that a virus isolated from chayote crops in Central America (21) named ChMV represents a new tymovirus. $\mathrm{ChMV}$ is the first tymovirus mainly infecting species in the $\mathrm{Cu}-$ curbitaceae to be fully characterized at the molecular level. Contrary to what has been reported (41), we found that the fairly specialized host range of tymoviruses does not correlate with serological affinities or sequence similarities. The case of ChMV presented here is a clear example of this lack of correlation, as ChMV showed serological and sequence similarities with two tymovirus species (i.e., EMV and APLV) of proximal geographical provenance but different natural host ranges and less similarity with the cucurbit-infecting tymoviruses described to date. Among the several tymovirus CP genes compared, ChMV CP was closest (by serological and molecular analyses) to EMV and APLV, two tymoviruses infecting Solanaceae and reported in the Caribbean Basin (EMV) and South America (APLV). Among the six tymovirus species fully sequenced to date, the RP gene of ChMV was also closely related to that of EMV. These three viruses (APLV, ChMV, and EMV) may have evolved to their specialized host ranges from a common ancestor in the Central-South American region. Compared with APLV and EMV, neither of two cucurbitinfecting tymoviruses (MRMV, reported in Middle East countries and WCMV, reported in the United States) were as similar serologically or in sequence to ChMV. The complete genetic structure of ChMV opens the possibility of searching for genetic determinants in the tymovirus genome involved in infection of Cucurbitaceae.

\section{ACKNOWLEDGMENTS}

This work was supported by contract CI1 CT940040 of the ALAMED Program (European Commission).

\section{LITERATURE CITED}

1. Ball, E. M. 1990. Agar double diffusion plates (Ouchterlony): Viruses. Pages 111-120 in: Serological Methods for Detection and Identification of Viral and Bacterial Plant Pathogens. R. Hampton, E. Ball, and S. De Boer, eds. The American Phytopathological Society, St. Paul, MN.

2. Bernal, J. J., and García-Arenal, F. 1997. Analysis of the in vitro secondary structure of cucumber mosaic virus satellite RNA. RNA 3:10521067.

3. Bozarth, C. S., Weiland, J. J., and Dreher, T. W. 1992. Expression of ORF-69 of turnip yellow mosaic virus is necessary for viral spread in plants. Virology 187:124-130.

4. Bransom, K. L., and Dreher, T. W. 1994. Identification of the essential cysteine and histidine residues of the turnip yellow mosaic virus protease. Virology 198:148-154.

5. Bransom, K. L., Wallace, S. E., and Dreher, T. W. 1996. Identification of the cleavage site recognized by the turnip yellow mosaic virus protease. Virology 217:404-406.

6. Deiman, B. A. L. M., Koenen, A. K., Verlaan, P. W. G., and Pleij, C. W. A. 1998. Minimal template requirements for initiation of minus-strand synthesis in vitro by the RNA-dependent RNA polymerase of turnip yellow mosaic virus. J. Virol. 72:3965-3972.

7. Ding, S., Howe, J., Keese, P., Mackenzie, A., Meek, D., Osorio-Keese, M., Skotnicki, M., Srifah, P., Torronen, M., and Gibbs, A. 1990. The ty- mobox, a sequence shared by most tymoviruses: Its use in molecular studies of tymoviruses. Nucleic Acids Res. 18:1181-1187.

8. Ding, S., Keese, P., and Gibbs, A. 1989. Nucleotide sequence of the ononis yellow mosaic tymovirus genome. Virology 172:555-563.

9. Ding, S., Keese, P., and Gibbs, A. 1990. The nucleotide sequence of the genomic RNA of Kennedya yellow mosaic tymovirus-Jervis Bay isolate: Relationships with potex- and carlaviruses. J. Gen. Virol. 71:925-931.

10. Dreher, T. W., and Goodwin, J. B. 1998. Transfer RNA mimicry among tymoviral genomic RNAs ranges from highly efficient to vestigial. Nucleic Acids Res. 26:4356-4364.

11. Edwards, M. C., Zhang, Z., and Weiland, J. J. 1997. Oat blue dwarf marafivirus resembles the tymoviruses in sequence, genome organization, and expression strategy. Virology 232:217-229.

12. Fichot, O., and Girard, M. 1990. An improved method for sequencing of RNA templates. Nucleic Acids Res. 18:6162.

13. Gibbs, A. 1999. Tymoviruses. Pages 1850-1853 in: Encyclopedia of Virology Vol. 3. A. Granoff and R. Webster, eds. Academic Press, U.K.

14. Gorbalenya, A. E., and Koonin, E. V. 1993. Helicases: Amino acid sequence comparisons and structure-function relationships. Curr. Opin. Struct. Biol. 3:419-429

15. Guy, P. L., Dale, J. L., Adena, M. A., and Gibbs, A. 1984. A taxonomic study of the host ranges of tymoviruses. Plant Pathol. 33:337-346.

16. Hellendoorn, K., Mat, A. W., Gultyaev, A. P., and Pleij, C. W. A. 1996. Secondary structure model of the coat protein gene of Turnip yellow mosaic virus RNA: Long, C-rich, single-stranded regions. Virology 224:43-54.

17. Hellendoorn, K., Michiels, P. J. A., Biutenhuis, R., and Pleij, C. W. A. 1996. Protonatable hairpins are conserved in the $5^{\prime}$-untranslated region of tymovirus RNAs. Nucleic Acids Res. 24:4910-4917.

18. Hellendoorn, K., Verlaan, P. W. G., and Pleij, C. W. A. 1997. A functional role for the conserved protonatable hairpins in the $5^{\prime}$ untranslated region of turnip yellow mosaic virus RNA. J. Virol. 71:8774-8779.

19. Henikoff, S., and Henikoff, J. G. 1992. Amino acid substitution matrices from protein blocks. Proc. Natl. Acad. Sci. USA 89:10915-10919.

20. Hirth, L., and Givord, L. 1988. Tymoviruses. Pages 163-212 in: The Plant Viruses Vol. 3. R. Koenig, ed. Plenum Press, New York.

21. Hord, M., Villalobos, W., Macaya-Lizano, A. V., and Rivera, C. 1997. Chayote mosaic, a new disease in Sechium edule caused by a tymovirus. Plant Dis. 81:374-378.

22. Jones, P., Angood, B., and Carpenter, J. M. 1986. Melon rugose mosaic virus, the cause of a disease of watermelon and sweetmelon. Ann. Appl. Biol. 108:303-307.

23. Kadaré, G., and Haenni, A.-L. 1997. Virus-encoded RNA helicases. J. Virol. 71:2583-2590.

24. Keese, M. E. O., Keese, P., and Gibbs, A. 1989. Nucleotide sequence of the genome of eggplant mosaic tymovirus. Virology 172:547-554.

25. Kluge, A. G., and Farris, J. S. 1969. Quantitative phyletics and the evolution of anurans. Syst. Zool. 18:1-32.

26. Koenig, R. 1976. A loop structure in the serological classification system of tymovirus. Virology 72:1-5.

27. Koenig, R., Fribourg, C. E., and Jones, R. A. C. 1979. Symptomatological, serological, and electrophoretic diversity of isolates of Andean potato latent virus from different regions in the Andes. Phytopathology 69:748-752.

28. Koenig, R. and Lesemann, D. E. 1981. Tymoviruses. Pages 33-60 in: Handbook of Plant Virus Infections. E. Kurstak, ed. Elsevier Science Publishing Co., Holland

29. Koonin, E. V. 1991. The phylogeny of RNA-dependent RNA polymerases of positive-strand RNA viruses. J. Gen. Virol. 72:2197-2206.

30. Mahgoub, H. A., WipfScheibel, C., Delecolle, B., Pitrat, M., Dafalla, G., and Lecoq, H. 1997. Melon rugose mosaic virus: Characterization of an isolate from Sudan and seed transmission in melon. Plant Dis. 81:656660.

31. Milne, K. S., Grogen, R. G., and Kimble, K. A. 1969. Identification of viruses infecting cucurbits in California. Phytopathology 59:919-928.

32. Morch, M. D., Drugeon, G., Szafranski, P., and Haenni, A.-L. 1988. Overlapping open reading frames revealed by complete nucleotide sequencing of turnip yellow mosaic virus genomic RNA. Nucleic Acids Res. 16:6157-6173.

33. Pinck, M., Yot, P., Chapeville, F., and Duranton, H. 1970. Enzymatic binding of valine to the $3^{\prime}$ end of TYMV-RNA. Nature (London) 226:954-956.

34. Ranjith-Kumar, C. T., Gopinath, K., Jacob, A. N. K., Srividhya, V., Elango, P., and Savithri, H. S. 1998. Genomic sequence of Physalis mottle virus and its evolutionary relationship with other tymoviruses. Arch. Virol. 143:1489-1500.

35. Rietveld, K., van Poelgeest, R., Pleij, C. W. A., van Boom, J. H., and Bosch, L. 1982. The tRNA-like structure at the 3' terminus of Turnip yellow mosaic virus RNA: Differences and similarities with canonical 
tRNA. Nucleic Acids Res. 10:1929-1946.

36. Rozanov, M. N., Drugeon, G., and Haenni, A.-L. 1995. Papain-like proteinase of turnip yellow mosaic virus: A prototype of a new viral proteinase group. Arch. Virol. 140:273-288.

37. Rozanov, M. N., Koonin, E. V., and Gorbalenya, A. E. 1992. Conservation of the putative methyltransferase domain: a hallmark of the "Sindbis-like" supergroup of positive-strand RNA viruses. J. Gen. Virol. 73:2129-2134.

38. Saitou, N., and Nei, M. 1987. The neighbor joining method, a new method for reconstructing phylogenetic trees. Mol. Biol. Evol. 4:406-425.

39. Sambrook, J., Fritsch, E. F., and Maniatis, T. 1989. Molecular Cloning: A Laboratory Manual. 2nd ed. Cold Spring Harbor Laboratory, Cold Spring Harbor, NY.

40. Singh, R. N., and Dreher, T. W. 1998. Specific site selection in RNA resulting from a combination of nonspecific secondary structure and
CCR- boxes: Initiation of minus strand synthesis by turnip yellow mosaic virus RNA-dependent RNA polymerase. RNA 4:1083-1095.

41. Srifah, P., Keese, P., Weiller, G., and Gibbs, A. 1992. Comparisons of the genomic sequences of erysimum latent virus and other tymoviruses: A search for the molecular basis of their specificities. J. Gen. Virol. 73:1437-1447.

42. Thompson, J. D., Higgins, D. G., and Gibson, T. J. 1994. CLUSTAL W: Improving the sensitivity of progressive multiple alignment through sequence weighting, position-specific gap penalties, and weight matrix choice. Nucleic Acids Res. 22:4673-4680.

43. van Batenburg, F. H. D., Gultyaev, A. P., and Pleij, C. W. A. 1995. An APL-programmed genetic algorithm for the prediction of RNA secondary structure. J. Theor. Biol. 174:269-280.

44. Zuker, M. 1989. On finding all suboptimal foldings of an RNA molecule. Science 244:48-52. 